\title{
RELASI TEOLOGI ASWAJA DENGAN HAM PERSPEKTIF KIAI SAID AQIL SIROJ
}

\author{
Budi Harianto*
}

Abstract: The definition of Abl al-Sunnah Wa al-Jama'ah resulted from the construction of Kiai Said Aqil Siroj's thought ie Abl alSunnah Wa al-Jama'ah as manhaj al-fikr al-din al-syamil 'ala syu'un al-hayat wa muqtadhayatiba al-qaim 'ala asas al-tawassuth wa al-tawazun wa al i'tidad wa al-tasamuh (a method of religious thought that encompasses all aspects of life and stands on the principle of equilibrium in aqidah, mediator and adhesive in social life, and justice and tolerance in politics). Kyai Said Aqil Siroj's typology of thought is an inclusive (open) religious typology and the Abl al-Sunnab Wa alJama'ah perspective of Kiai Said can be said of the inclusiveness of $A b l$ al-Sunnab Wa al-Jama'ah. So Abl al-Sunnah Wa al-Jama'ah must contain tawasut, tasamuh, tawazun and 'tidal in acting or thinking. So as to respond to new things in modern life such as human rights.

Keywords: HAM, Ablas-Sunnah Wa-al Jama'ah, Justice, Freedom, Equality.

\section{A. Pendahuluan}

Pandangan pemikiran holistik tentang Abl as-Sunnab Wa-al Jama'ah di Indonesia digunakan sebagai paham keagamaan mayoritas organisasi keagamaan umat Islam. Dua Organisasi keagamaan yang paling besar dan sama-sama menyatakan dirinya sebagai representasi dari kelompok Abl as-Sunnab Wa-al Jama'ah adalah NU dan Muhammadiyah, meskipun

* Dosen Fakultas Ushuluddin, Adab, Dan Dakwah IAIN Tulungagung budibarianto744@gmail.com 
Muhammadiyah tidak secara formal dan konkrit menyatakan diri sebagai pengikut $A$ bl as-Sunnab Wa-al Jama'ah, karena lebih fokus pada gerakan tajdid (pembaharuan). Dalam risalah-risalah resmi Muhammadiyah, tidak ada istilah $\mathrm{Abl}$ as-Sunnah Wa al-Jama'ah. Istilah yang digunakan ialah Firqatun Najiyyah. Muhammadiyah dalam konteks di Indonesia tidak mengklaim diri secara verbal sebagai $A$ bl as-Sunnah Wa-al Jama'ah, tetapi jika dikaitkan dengan ajaran Syiah, Muhammadiyah jelas memposisikan diri sebagai Abl as-Sunnab Wa-al Jama'ah

Selain itu pandangan Abl al-sunnab wa al-jama'ab oleh kalangan NU dirumuskan sebagai landasan berpikir, bersikap, dan bertindak. Sementara Islam reformis merumuskan Abl al-sunnab wa al-jama'ab sebagai teori dan praktek yang menyangkut dimensi lahir dan batin. Pandangan tersebut dirinci dalam berbagai disiplin keilmuan dan agenda kegiatan sosial, sehingga pengertian $A$ bl al-sunnab wa al-jama'ab kemudian tidak hanya meliputi doktrin teologi (akidah) tetapi juga berkembang pada wilayah ideologi pembaharuan sosial.

Dimensi dasar kemanusiaan ini, di era modern, menjadi agenda PBB untuk dijadikan norma internasional yang menuntut semua negara, khususnya para anggota, menghargai nilai-nilai dasar dan hak-hak asasi manusia yang merupakan hak yang harus dipenuhi seseorang dan dijunjung tinggi oleh semua orang. Hak tersebut merupakan pembawaan ketika manusia ada. Secara resmi PBB sebagai lembaga koordinasi semua urusan dunia, mengundang banyak negara untuk ikut meresmikan dan memproklamirkan disahkannya peraturan terkait hak-hak dasar manusia melalui "Universal Declaration of Human Rights" (Deklarasi Universal Hak Asasi Manusia) pada Desember tahun 1948.

\section{B. Biografi Singkat Kiai Said Aqil Siroj}

Kiai Said Aqil Siroj, dilahirkan dari pasangan Kiai Aqil Siroj dan Afifah Harun dilahirkan pada tanggal 03 Juli 1953, tempat kelahiran beliau di Cirebon. KH. Aqil Siroj (al-Maghfurlah), merupakan pengasuh Pondok Pesantren Tarbiyatul Mubtadi' in Kempek Palimanan Cirebon. Lokasi pondok ini tak persis berada di pinggir jalan, bahkan harus masuk beberapa puluh meter. Tepatnya bangunan itu berada di tengah-tengah area persawahan. Berdiri di atas lahan seluas lima hektar, pesantren 
Kempek ini dirintis oleh almarhum Kiai Harun pada tahun 1908. Setelah dia meninggal tahun 1957, upaya pendidikan dilanjutkan oleh putranya yang pertama yakni Kiai Yusuf yang juga menantu dari Kyai Munawir dari Jakarta. Dan setelah itu diteruskan oleh Kyai Umar dan Kyai Nasir. Dari generasi Kyai Nasir inilah pesantren Kempek ini dikelola. Penerus mereka adalah Kiai Ja'far Shodiq Aqil Siroj, Kiai Said Aqil Siroj, Kiai Musthafa Aqil Siroj, Kiai Ahsin Aqil Siroj, dan Kiai Ni'am Aqil Siroj. ${ }^{1}$

Kang Said (panggilan akrabnya) menikah dengan Nur Hayati Abdul Qodir dikaruniai empat orang anak (dua putera dan dua puteri), yaitu Muhammad Said Aqil, Nisrin Said Aqil, Rihab Said Aqil, dan Aqil Said Aqil.

Pendidikan Kang Said diawali "ngaji” di pesantren ayahnya yang masih mengacu pola tradisional, sambil Sekolah Rakyat (SR) tahun 1965, kemudian melanjutkan studi ke Pondok Pesantren Hidayatul Mubtadi'en Lirboyo Kediri hingga menyelesaikan tingkat menengah atas tahun $1970 .{ }^{2}$

Selepas dari pesantren salaf (tradisional) asuhan pamannya, KH.Mahrus Ali (Al-Maghfurlah) tersebut, Kang Said mengayunkan langkahnya ke kota gudeg Yogyakarta untuk menimba ilmu dari KH. Ali Ma'shum (Al-Maghfurlah) di Pondok Pesantren Krapyak, sambil studi di Fakultas Adab IAIN Sunan Kalijaga Yogyakarta. Merasa belum puas dengan pengkajian di kota gudeg, Kang Said berketetapan untuk mencari ilmu ke Timur Tengah.

Pada tahun 1979, dia berkesempatan kuliah di Arab Saudi. Pada tingkat lisanis (S1), dia kuliah di Universitas King Abd Al Aziz (sekarang menjadi Ummu al-Qura) dan selesai pada tahun 1983. Kemudian pada tingkat S2, dia meneruskan di Universitas yang sama selesai pada tahun 1987 dengan judul tesis "Rasail al-Rusul fi Al-Abdi Al-Jadid wa Atsaruba fi Inbiraf Al Masibiyah (Surat-surat Para Rasul pada Perjanjian Baru dan Pengaruhnya terhadap Perubahan Agama Kristen. ${ }^{3}$ Kepiawaiannya nampak pada saat puncak studi S-3, tatkala ujian munaqasyah (promosi)

1 Joko Syahban, Ensiklopedi NU, (Pekalongan: Dwi Kaharjaning Gesang, 2010), 244.

2 Hatta Hasan, Islam Kebangsaan Demokratik Kaum Santri, (Jakarta: Fatma Press, 1999), iii.

3 Mujamil Qomar, NU "Liberal" dari Tradisionalisme Ablssunnab ke Universalisme Islam, (Bandung: Mizan, 2002), 187. 
doktor. Disertasi yang bertitel "shillatullahi bil-kaun fit-tashawwuf alfalsafi” (Relasi Tuhan dengan alam kosmos: perspektif Tasawuf Filosofis) benar-benar menggemparkan Ummu al-Qura yang notabene mengharam-kan diskursus tasawuf filosofis. Anehnya, justru Kang Said mampu mempertahankan dengan predikat terpuji (mumtaz, cumloude), selesai pada tahun $1994 .^{4}$

Sepulangnya di Indonesia, namanya semakin dikenal saat diberi amanah untuk memangku jabatan Wakil Katib 'Aam Shuriyah PBNU hasil Muktamar Cipasung 1994. Namun, belum genap tiga bulan memangku jabatan tersebut, di tengah kelompok yang tak puas atas hasil Muktamar Cipasung. Kang Said menjadi sasaran tembak sebagai agen syi' ah. Orasinya dihadapan PMII seputar latar belakang lahirnya $A b l$ al-Sunnah Wa al-Jama'ah mendapat kritikan tajam dari berbagai pihak, sampai muncul pengkafiran pada dirinya oleh 12 orang Kyai. Meskipun demikian, saat diadakan tabayyun (klarifikasi) oleh para Kyai, justru disitu nampak kecerdasan kyai muda tersebut dalam memahami Islam. PBNU pun akhirnya menggelar halaqah khusus untuk merekonstruksi ASWAJA, suatu doktrin yang selama ini disakralkan. ${ }^{5}$

Dua tahun kemudian, ia menjadi sorotan publik kembali, setelah berkhotbah di Gereja Algonz Surabaya. Seperti pada kasus sebelumnya, tidak sedikit para kyai yang memberis tempel "kafir" padanya. Polemik itu pun akhirnya justru semakin meyakinkan kedalaman dan keluasan ilmu Kang Said. Tidak hanya warga NU atau umat Islam saja yang perlu mengaji padanya, tapi orang-orang non muslim pun sangat membutuhkan petuah-petuahnya untuk menjadi pemeluk agama yang baik dan benar. Karenanya, praktis kesibukan Direktur dan Guru Besar Pascasarjana Universitas Islam Malang, yang juga dosen pascasarjana UIN Syarif Hidayatullah Jakarta serta Universitas Surabaya itu semakin meningkat frekuensinya. Di pentas nasional, aktivitas Kang Said mulai nampak saat dipercaya sebagai wakil ketua Tim Gabungan Pencari Fakta (TGPF) kerusuhan Mei 1998, ketua Forum Komunikasi Kesatuan Bangsa (FKKB), penasehat Pusat Kajian Timur Tengah dan Islam Universitas Indonesia, hingga akhirnya diangkat menjadi ketua Tim Gabungan Pencari Fakta (TGPF) kasus pembantaian dukun santet Banyuwangi.

\footnotetext{
4 Hatta Hasan, Islam Kebangsaan, iii.

5 Ibid., iv.
} 
Terlebih lagi, karier beliau benar-benar melejit ketika di jajaran PBNU, setelah berdirinya PKB, beliau naik menjadi Katib'Aam Syuriyah pada tahun 1999. ${ }^{6}$ Kemudian Kang Said terpilih menjadi, Ketua Umum Tanfidizah Pengurus Besar Nahdlatul Ulama (PBNU) periode 2010-2015 lewat Muktamar ke-32 Nahdlatul Ulama (NU) di Asrama Haji Sudiang, Makassar, Sulawesi Selatan. Dan di Tahun 2015 terpilih kembali sebagai Ketua Umum Tanfidizah PBNU pada Muktamar ke-33 di Jombang.

\section{Sejarah Abl Al-Sunnab Wa Al-Jama'ab}

Abl al-Sunnah Wa al-Jama'ah dalam sejarah kemunculanya dan term istilahnya banyak mengalami perbedaaan. Hal ini dikarenakan Abl al-Sunnab Wa al-Jama'ah beda dengan syi'ah, Mu'tazilah, khawarij dan lain sebagainya. Nama-nama tersebut jelas merupakan aliran yang menisbatkan dirinya melembaga sebagai aliran. Hal ini yang membedakan dengan Abl al-Sunnah Wa al-Jama'ah yang terkadang masih bias apakah sebagai aliran, paham, madzhab, manhaj atau yang lainnya.

Konsep Abl al-Sunnab Wa al-Jama'ab selama ini masih belum dipahami secara tuntas, sehingga menjadi "rebutan" setiap golongan. Semua kelompok mengaku dirinya sebagai penganut ajaran Ablal-Sunnah Wa al-Jama'ah. Tidak jarang, label itu digunakan untuk kepentingan sesaat.

Abl al-Sunnah $\mathrm{Wa}$ al-Jama'ah lahir dari pergulatan intens antara doktrin dengan sejarah. Di wilayah doktrin, debat meliputi soal kalam mengenai status al Qur'an apakah ia makhluk atau bukan, kemudian debat antara sifat-sifat Allah antara ulama salafiyyun dengan golongan Mu'tazilah.

Golongan Mu'tazilah berpendapat bahwa kalam Allah swt bukan sifat, akan tetapi merupakan perbuatan Tuhan. Oleh sebab itu, al Qur'an tidak bersifat qadim, akan tetapi bersifat baru dan diciptakan, dengan argumentasi bahwa al Qur'an itu terdiri dari susunan huruf-huruf, katakata, ayat-ayat dan surat-surat, yang huruf yang satu mendahului huruf yang lain, ayat yang satu mendahului ayat yang lain, dan surat yang satu mendahului surat yang lain. Huruf hamzah dalam kalimat al-hamdu lillahi, misalnya, telah mendahului huruf lam, dan huruf lam mendahului

\footnotetext{
${ }^{6}$ Ibid., iv.
} 
huruf ha. Sedangkan qadim (kekal) adalah sesuatu yang tidak bermula dan tidak didahului oleh suatu apapun. Pandangan golongan Mu'tazilah ini didasarkan pada firman Allah saw dalam surat al-Anbiya' ayat 2, surat al-Hijr ayat 9, surat Hud ayat 1 dan surat az-Zumar ayat 23. ${ }^{7}$

Pada wilayah sejarah, Islam mengalami fitnah-fitnah, Alfitnatul Qubra. Ada fitnah besar yang mempengaruhi jalan pikiran dan perkembangan pemahaman Islam. Yaitu, pertama pembunuhan Usman. Kedua, peperangan Ali dengan Muawiyah, dan Ali dengan Aisyah (mertuanya dan sekaligus istri Nabi). Kemudian yang ketiga, pengejaran habis-habisan keturunan Umayyah oleh keturunan Abbasiyah pada waktu revolusi Abbasiyah. Sebetulnya malah ada satu lagi fitnah yang keempat, yang juga berpengaruh atas proses pemahaman tentang agama. Yaitu perang antara dua bersaudara putra Harun Alrosyid (antara Amin dan Ma'mun).

Di antara keempat fitnah itu, yang paling besar pengaruhnya ialah fitnah yang pertama dan kedua. Pembunuhan Usman dan peperangan Ali dengan yang lain-lain (Aisyah dan Muawiyyah) itulah yang kemudian menimbulkan golongan Syi'ah, yang arti harfiahnya "partai" (syi'atu Ali, berarti partai Ali). Semua istilah itu bersifat netral sekali, yakni kelompok Ali. Tetapi kemudian ia menjadi istilah yang syarat sekali dengan ideologi. Kaum Syi'ah ini cenderung menganggap, bahwa yang bukan golongan mereka adalah kafir. Sedangkan kaum Umayyah juga mengkafirkan Ali. Bani Umayyah waktu itu memang hanya mengakui Abu Bakar, Umar dan Usman. Sebaliknya orang Syi'ah cuma mengakui Ali sehingga kemudian disebut kaum rafidhah (penolak). Kita tahu, bahwa kemudian ada juga kelompok Ali yang memisahkan diri dalam bentuk Khawarij, disebabkan kekecewaan mereka terhadap Ali yang mau mengadakan kompromi dengan Muawiyah. Mereka mengkafirkan, baik Ali maupun Muawiyah.

Sejak itu ada moment yang di dalamnya sejarah Islam dihitamkan oleh gejala kafir mengkafirkan (takfir) sesama muslim, terutama yang dilancarkan oleh orang Khawarij. Kelompok Khawarij ini bersifat idealis, dalam arti sangat utopis. Sehingga misalnya orang yang tidak mengerti al Qur'an adalah kafir. Lalu sebagai rentetannya kalau seseorang telah dinyatakan kafir berarti ia berada dalam darul harb, sehingga wajib diperangi. Orang yang menolak memerangi pun pada gilirannya dianggap

7 Husein Aziz, Bahasa Al Qur'an Perspektif Filsafat Ilmu, (Pasuruan: Sidogiri, 2002), 39. 
kafir juga. Terjadilah chaos. Rumusan tentang siapa muslim dan siapa kafir pada waktu itu ekstrim sekali. Terutama yang diajukan oleh Khawarij.

Secara linguistik Abl al-Sunnab $\mathrm{Wa}$ al-Jama'ah adalah istilah yang tersusun dari tiga kata:

1. Kata $A h l$, yang berarti keluarga, pengikut, atau golongan ${ }^{8}$

2. Kata al-Sunnah mengandung pengertian konsistensi terhadap tradisi nabi dan sahabat. Sehingga dalam istilah ini juga terkandung ide bahwa pendukung aliran tersebut bersungguh-sungguh ingin mempresentasikan Islam secara murni dan menghindarkan sejauhjauhnya bid'ah (pranata keagamaan baru yang tidak didapati dasarnya dalam nass, tetapi diklaim sebagai bagian dari agama). ${ }^{9}$

3. Al-jama'ah adalah sekumpulan orang yang memiliki tujuan. Jika kata ini dikaitkan dengan sekte-sekte Islam (al-mazahib al-Islamiyyah), maka hanya berlaku di kalangan Ahl-Sunnah karena di kalangan Khawarij ataupun Rafidhah belum dikenal penggunaan kata aljama'ah. Sementara itu, di kalangan Mu'tazilah tidak menerima Ijma' sebagai suatu produk hukum. ${ }^{10}$

Akar perkembangan Abl al-Sunnab wa al-Jama'ah sebagai aliran, sekte, atau paham keagamaan dapat dilacak dari fenomena kemunculan berbagai firqah (golongan, kelompok) di kalangan umat Islam pada masa Khulafa al-Rashidin. Lahirnya firqah-firqah itu mula-mula berlatar belakang politik, yakni problem suksesi pasca Nabi. ${ }^{11}$

Menurut mayoritas ulama sejak generasi salaf yang saleh, Abl alSunnah Wa al-Jama'ah adalah kelompok yang mengikuti ajaran Islam yang murni dan asli, seperti yang diajarkan oleh Nabi saw dan sahabatnya. Abl al-Sunnab Wa al-Jama'ab merupakan kelangsungan alamiah dari perjalanan sejarah Islam yang masih asli dan murni, yang pada gilirannya layak menjadi golongan yang selamat (al-firqah al-najiyah). ${ }^{12}$

Perlu diketahui, bahwa dalam perjalanan sejarah Islam, tidak semua

${ }^{8}$ Muhammad Idrus Ramli, Madzhab Al-Asy'ari Benarkah Ablsunnah Wal Jama'ah? Jawaban terbadap Aliran Sesat, (Surabaya: Khalista, 2009), 175.

9 Achmad Muhibbin Zuhri, Pemikiran KH.M.Hasyim Asy'ari tentang Abl AlSunnah Wal Al-Jama'ah, (Surabaya: Khalista, 2010), 37.

${ }^{10}$ Said Agiel Siradj, Ablssunnah Wal Jama'ah dalam Lintasan Sejarah, (Yogyakarta: LKPSM, 1998), 18.

${ }^{11}$ Achmad Muhibbin Zuhri, Pemikiran KH.M.Hasyim, Ibid., 39.

${ }^{12}$ Muhammad Idrus Ramli, Madzhab Al-Asy'ari, Ibid., 232. 
aliran yang ada dalam Islam mengklaim dirinya atau diakui sebagai pengikut Abl al-Sunnab Wa al-Jama'ah. Kelompok Syiah, Khawarij, Mu'tazilah, Zaidiyah dan Ibadhiyah misalnya, tidak mau dikatakan sebagai pengikut Abl al-Sunnab Wa al-Jama'ah. Dalam perjalanan sejarah, hanya ada dua aliran yang mengklaim dirinya sebagai pengikut dan mewakili madzhab Abl al-Sunnab Wa al-Jama'ah, yaitu aliran yang mengikuti madzhab al-Asy'ari dan al-Maturidi, dan aliran yang mengikuti paradigma pemikiran Ibn Taimiyah al-Harrani. Kedua aliran inilah yang mengklaim dirinya masih mengikuti dan mewakili Ablal-Sunnab Wa alJama'ah, sementara kelompok yang lain divonisnya termasuk kelompok Ahli bid'ah. Meski demikian, dalam sejarah konflik pemikiran dan ideologis yang terjadi antara aliran yang mengikuti madzhab al-Asy'ari dan al-Maturidi disatu pihak, dan aliran yang mengikuti paradigma Ibn Taimiyah al-Harrani di pihak lain, selalu dimenangkan oleh aliran yang pertama, yaitu aliran yang mengikuti madzhab al-Asy'ari dan alMaturidi. ${ }^{13}$

Dalam kajian Ilmu Kalam, istilah Abl al-Sunnab Wa al-Jama'ah ini sudah banyak dipakai sejak masa sahabat, sampai generasi-generasi berikutnya. Penyebutan Ablal-Sunnab Wa al-Jama'ah ini juga digunakan untuk membedakan kelompok ini dari kelompok lain seperti Syiah, Khawarij, Mu'tazilah, dan Murji'ah. Dan para imam madzhab fiqih seperti Imam Abu Hanifah (w 150 H), Imam Malik bin Anas (w. 179 H), Imam As-Syafi'i (w. 240 H) dan Imam Abu Hambal (w. 241 H) dikenal sebagai tokoh-tokoh Ahlssunah, sebelum munculnya Imam Al-Asy'ari, Imam AlMaturidi, dan Imam At-Thohawi sebagai tokoh Mutakallimin (Ahli Ilmu Kalam) dari kalangan Ahlssunah pada abad ke-3 H. Sumber dari istilah tersebut oleh sebagian banyak para Ahli diambil dari hadits Nabi saw yang menerangkan akan terpecahnya umat Islam menjadi 73 golongan. ${ }^{14}$

Terlepas dari historis di atas, sejak kurun pertama hijriah banyak perdebatan yang bisa kita nikmati secara alamiah dan ilmiah, misalnya kitab Maqalat al-Islamiyyin yang ditulis oleh Imam Al-Asy'ari (w. 324/935) dan kitab al Faraq baynal Firaq oleh Al-Bagdadi (w. 429/1037). Direkam dengan sangat rinci bagaimana silang pendapat terjadi antara

${ }^{13}$ Ibid., 233.

${ }^{14}$ Muhammad Tholhah Hasan, Ablssunnah wal Jama'ah dalam Persepsi dan Tradisi NU, (Jakarta: Lantabora Press, 2005), 4. 
tokoh-tokoh Mu'tazilah, Syiah, Murji'ah, dan Ahlussunnah wal Jama'ah. Jelas tergambar tidak hanya kemajemukan tapi juga kedewasaan para cendekiawan pada saat itu dalam berpendirian dan berargumentasi secara santun, ilmiah, dan rasional. Melihat hal tersebut $A b l$ al-Sunnab Wa al-Jama'ah tidak lahir dari ruang kosong tetapi ada latar yang melatarbelakanginya. ${ }^{15}$

\section{Relasi Teologi Aswaja Dengan HAM Perspektif Kiai Said Aqil Siroj}

Konsep Abl al-Sunnab Wa al-Jama'ab menurut Kiai Said Aqil Siroj bahwa Abl al Sunnab Wa al-Jama'ab itu bukan madhdhab, tetapi sekedar manhaj al-fikr. Sebab ia hanya sekedar upaya mencari jalan tengah antara berbagai aliran yang ada.

Definisi Abl al-Sunnah Wa al-Jama'ah menurut Kiai Said Aqil Siroj sebagai manhaj al-fikr al-din al-syamil 'ala syu'un al-hayat wa muqtadhayatiha al-qaim 'ala asas al-tawassuth wa al-tawazun wa al i'tidad wa al-tasamuh (metodologi berpikir keagamaan yang mencakup segala aspek kehidupan dan berdiri di atas prinsip keseimbangan dalam akidah, penengah, dan perekat dalam kehidupan sosial, serta keadilan dan toleransi dalam politik.

Kemoderatan Ablal-Sunnah Wa al-Jama'ah pada metode pengambilan hukum (istinbath) yang tidak semata-mata menggunakan nash, namun juga memperhatikan posisi akal. Begitu pula dalam wacana berpikir selalu menjembatani antara wahyu dengan rasio (al-ra'y). Metode (manhaj) seperti inilah yang diimplementasikan oleh Imam madhdhab empat serta generasi lapis berikutnya dalam menelorkan hukum-hukum pranata sosial.

Sifat netral (tawazun) Abl al-Sunnab Wa al-Jama'ab berkaitan dengan sikap mereka dalam politik. Abl al-Sunnab Wa al-Jama'ah tidak terlalu membenarkan kelompok garis keras (ekstrim). Akan tetapi, jika berhadapan dengan penguasa yang zalim, mereka tidak segan-segan mengambil jarak dan mengadakan aliansi. Dengan kata lain, suatu saat mereka bisa akomodatif, suatu saat bisa lebih dari itu meskipun masih dalam batas tawazun .

Ta'adul (keseimbangan) Abl al-Sunnah Wa al-Jama'ah terefleksikan

${ }^{15}$ Budi Harianto, “Tawaran Metodologi Fazlur Rahman dalam Teologi Islam”, Kontemplasi Jurnal Ilmu-Ilmu Usbuluddin, Vol. 04, No.02. Desember 2016,279. 
pada kiprah mereka dalam kehidupan sosial, cara mereka bergaul serta kondisi sosial budaya mereka. Begitu pula sikap toleran Ahl al-Sunnah Wa al-Jama'ah tampak dalam pergaulan dengan sesama muslim yang tidak mengkafirkan $\mathrm{Abl}$ al-qiblat serta senantiasa ber-tasamub terhadap sesama muslim maupun umat manusia pada umumnya. ${ }^{16}$

Dengan demikian cakupan Ablal-Sunnah Wa al-Jama'ah sangat luas, termasuk dalam bidang aqidah. Kita tidak bisa membatasi $A$ hl al-Sunnah Wa al-Jama'ah hanya dengan pendapat al-Asy'ari karena jauh sebelumnya telah banyak pemikiran yang masuk dalam cakupan Abl al-Sunnab Wa al-Jama'ah. ${ }^{17}$

Jadi, Abl al-Sunnah Wa al-Jama'ab mengayomi seluruh aliran, sebagai perekat seluruh madhdhab. Dengan begitu Asy'ari, Maturidi, madhdhab empat, itu semua Sunni. Tapi bukan hanya itu saja yang Sunni. Bahkan kalau kita korek lagi, jalan tengahnya Asy'ari yang pernah sukses itu sekarang barangkali sudah tidak tengah lagi. Sudah pinggir. Persoalannya sudah semakin global, plural. Kalau masih menggunakan tengahnya Asy'ari, ya pinggir jadinya. Oleh karena itu, yang kita lihat adalah "manhaj tengah” nya itu, bukan Asy'arinya. Manhaj tawassuthnya kita gunakan untuk menyikapi perubahan. Justru disinilah salah satu karakter Sunni adalah selalu bisa beradaptasi dengan situasi dan kondisi.

Relasi HAM dengan Teologi Abl al-Sunnab Wa al-Jama'ah menurut Kiai Said Aqil Siroj sebenarnya tidak dijelaskan secara implisit atau secara formal. Namun ada beberapa elemen yang bisa diambil dari pemikiran Kiai Said Aqil Siroj dalam kaitanya dengan kebangsaan dan kemanusiaan yakni Syuro (Musyawarah), al-adl (keadilan), Al- Hurriyab (Kebebasan), dan $A l-M u s a w a b$ (kesetaraan derajat). Oleh karena itu menurut penulis, elemen tersebut menjadi substansi dari HAM.

Lahirnya Deklarasi Universal Hak Asasi Manusia (DUHAM) sebagai forum penilaian atas perilaku manusia di berbagai negara menimbulkan polemik, khususnya di negara-negara Islam. ${ }^{18}$ Keberatan-keberatan itu setidaknya berpusar pada dua hal. Pertama, negara Islam telah menjadikan

${ }^{16}$ Said Agiel Siradj, Ahlssunnah Wal Jama'ah, Ibid., 21.

${ }^{17}$ Ibid., 66.

${ }^{18}$ Bernard Lewis, et al, Islam Liberalisme Demokrasi, Membangun Sinergi Warisan Sejarah, Doktrin dan Konteks Global, terj. Mun'im A Sirry (Jakarta: Paramadina, 2002), 33. 
Islam sebagai kode etik dan standar penilaian perilaku masyarakat di negaranya .Dengan segala kelengkapannya dan ketersediaannya, Islam memiliki sendiri konsep penilaian terhadap manusia dan penghormatan terhadap hak-hak dasarnya, tanpa harus mengikuti DUHAM. Kedua, DUHAM merupakan produk Barat yang kental diselimuti ideologi, tradisi dan kultur yang dalam banyak hal bertentangan dengan Islam. DUHAM juga mengandung kepentingan-kepentingan politis, ekonomis dan antropologis bagi negara-negara yang sudah maju.

Hal tersebut tidak saja berseberangan dengan kepentingan negara berkembang atau Islam, namun yang lebih penting bagi negara Islam sendiri tidak menginginkan shari'ah Islam sebagai hukum Tuhan menjadi alternatif bagi DUHAM sebagai hukum buatan manusia. Perbedaan tersebut, khususnya dalam dunia Islam, masih terus bergulir, walaupun pembenahan-pembenahan terus dilakukan oleh lembaga internasional. ${ }^{19}$ Dalam konteks ini, banyak bermunculan para pemikir Islam memberikan gagasan terkait Islam dan HAM ini. Sebagian mereka memperkuat posisi Islam sebagai ideologi yang tidak bisa dicadangkan setelah DUHAM. ${ }^{20}$ Sebagian lain menyetujui adanya DUHAM sebagai kemaslahatan bersama seluruh umat manusia, yang oleh karenanya Islam harus merubah diri mengikuti kepentingan umum itu. ${ }^{21}$

Ada beberapa prinsip menurut Kiai Said dalam Teologi Ablal-Sunnah Wa al-Jama'ah yang diera modern ini hampir menyerupai dengan substansi dari HAM. Prinsip tersebut yakni sebagai berikut ${ }^{22}$ :

1. Hifzbu al-Nafs, yaitu jaminan atas jiwa (kehidupan) yang dimiliki warga negara (rakyat).

2. Hifzhu al-Din, yaitu jaminan kepada warga negara untuk memeluk agama sesuai dengan keyakinannya

3. Hifzhu al-Mal, yaitu jaminan tehadap keselamatan harta benda yang dimiliki oleh warga negara

4. Hifzhu al-Nasl, yaitu jaminan terhadap asal-usul, identitas, garis

${ }^{19}$ Robert Spencer, Islam Ditelanjangi, terj. Mun'im A. Sirry (Jakarta: Paramadina, 2004), 13.

${ }^{20}$ Sururin (ed), Nilai-nilai Pluralisme dalam Islam (Bandung: Nuansa, 2005), 19.

${ }^{21}$ Sidney Hook (dkk), Hak Asasi Manusia dalam Islam (Jakarta: Pustaka Firdaus, 1995), 17

${ }^{22}$ Said Agiel Siradj, Ablssunnab Wal Jama'ah,77 
keturunan setiap warga negara.

5. Hifzhu al-Irdh, yaitu jaminan terhadap harga diri, kehormatan, profesi, pekerjaan ataupun kedudukan setiap warga negara.

Dalam kaitannya dengan persamaan derajat dengan kebangsaan Kiai Said mengatakan bahwa semua warga negara haruslah mendapatkan perlakuan yang sama. Semua warga negara memiliki kewajiban dan hak yang sama pula. Sistem kasta atau pemihakan terhadap golongan, ras, jenis kelamin atau pemeluk agama tertentu tidaklah dibenarkan. ${ }^{23}$

Dari konskuensi kesetaraan derajat di atas maka sistem pemerintahan yang lebih mendekati cita-cita tersebut dalam pandangan Kiai Said adalah sistem demokrasi. Demokrasi yang dimaksud adalah sistem pemerintahan yang bertumpu kepada kedaulatan rakyat (civil society) sebagai amanat dari Allah. ${ }^{24}$

Menurut pandangan Kiai Said memang sistem demokrasi tidak pernah dijumpai dalam bahasa Al-Qur'an maupun wacana hukum Islam klasik. Istilah tersebut diadopsi dari para negarawan di Eropa.Namun, harus diakui bahwa nilai-nilai yang terkandung di dalamnya banyak menyerupai prinsip-prinsip yang harus ditegakkan dalam berbangsa dan bernegara menurut Aswaja. ${ }^{25}$

Sebagaimana Iswahyudi mengatakan pertama ma ana' alaibi adalah prinsip-prinsip keberagamaan yang berprofesi profetik: bergerak pada dua liberasi sekaligus. Prinsip ini menegaskan pola kerja teori menuju praksis, dari tauhid individual ke tauhid sosial dan dari gagasan ke perjuangan. Allah menjelaskan bahwa tauhid individual tanpa dilanjutkan tauhid sosial sesungguhnya merekalah pendusta Agama itu. Kedua, wa ashbabi, yaitu prinsip kesahabatan. Inilah prinsip keberagamaan setelah prinsip pertama, fungsi profetik. Sahabat Nabi adalah sahabat yang aktif dan kreatif, mampu melihat kepentingan-kepentingan sosial kulturalnya, misal, Umar mengorganisasikan tentara dan tidak memotong tangan pencuri. Utsman mengumpulkan al Qur'an untuk persatuan umat dan dia juga mengatakan hadith tersebut tidak terdapat dalam shabibhaini (Bukhari dan Muslim). ${ }^{26}$

\footnotetext{
${ }^{23}$ Ibid., 78.

${ }^{24}$ Ibid., 78.

${ }^{25}$ Ibid., 78.

${ }^{26}$ Iswahyudi, "Membongkar Hadis tentang Ahl Sunnah Wal Al-Jama'ah
} 
Perkembangan pemikiran dalam diri umat Islam seharusnya tidak dianggap sebagai sesuatu yang remeh dan enteng, jika umat Islam tidak ingin tertinggal oleh bangsa-bangsa di muka bumi ini.Tentu hal ini mengundang konsekuensi yang mendasar bagi umat Islam sebab pemekaran tersebut pasti banyak mengubah wacana pemikiran yang sudah ada (salaf/klasik) dan umat Islam harus secara dewasa menerima transformasi tersebut sepanjang tidak bertabrakan dengan hal-hal yang sudah paten (qath iy). Sebagai contoh, dalam kehidupan bernegara (baca: demokrasi), umat Islam harus dapat menerima seorang pemimpin (presiden) dari kalangan non-Muslim atau wanita. ${ }^{27}$

Sebagai contoh dalam era modern ini yang mana dunia sudah mengglobal dimana kondisi percaturan politik dan kehidupan umat manusia banyak mengalami perubahan yang mendasar, misalnya kalau dulu dikenal komunitas kabilah, saat ini sudah tidak dikenal lagi bahkan kondisi umat manusia sudah menjadi 'perkampungan dunia, maka demokrasi harus dapat ditegakkan. Pada masa lalu banyak ditemui ghanimah (harta rampasan perang) sebagai suatu sumber perekonomian negara. Sedangkan pada saat ini sistem perekonomian tersebut sudah tidak dikenal lagi. Perekonomian negara banyak diambil dari pajak dan pungutan lainnya. Begitu pula jika pada tempo dulu aqidah merupakan sentral kekuatan pemikiran, maka saat ini aqidah bukanlah merupakan satu satunya sumber pijakan. Umat sudah banyak berubah kepada pemahaman aqidah yang bersifat plural. ${ }^{28}$

Dalam menjembatani Teologi Abl al-Sunnab Wa al-Jama'ah dan HAM tidak saja sekedar mencari benang merahdari keduanya, tetapi memberikan penyadaran secara internal kepada keduanya. Kiai Said dalam hal ini berupaya melakukan ini dengan cara; ia terlebih dahulu mengevaluasi diri masing-masing, membuka kesadaran kedua akan pentingnya eksistensi dan perannya di dunia modern yang plural dan multikultural, serta memberikan alternatif-alternatif solutif bagi kemesraan antara keduanya, dan umumnya bagi semua masyarakat dunia. Dari situ, ia berusaha mengeksplorasi dan menginventarisasi

(Sebuah Pendekatan Critical Hermenutic: Jurgen Habermas”, Hermenia Jurnal Kajian Islam Interdisipliner, vol.3, No.2, Juli-Desember 2004, 283.

${ }^{27}$ Said Agiel Siradj, Ablssunnah Wal Jama'ah,79.

${ }^{28}$ Ibid., 79. 
terlebih dahulu problem-problem mengganjal yang ada di dalamnya. Dia merumuskan setidaknya ada dua problem yang mengganggu hubungan tersebut, yaitu; problem dari sisi umat Islam sendiri, dan problem dari luar; dunia secara lebih luas.

Hal yang perlu ditekankan disini kaitannya dengan kebebasan dalam HAM yakni menurut Kiai Said suatu jaminan bagi rakyat (umat) agar dapat melaksanakan hak-hak mereka. Hak-hak tersebut dalam syariat dikemas dalam al-Ushul al-Khams (lima prinsip pokok) yang menjadi kebutuhan primer (dharuri) bagi setiap insan sebagaimana yang telah di jelaskan di atas. ${ }^{29}$ Oleh sebab itu, Abl al-Sunnab Wa al-Jama'ab tidak jumud (mandeg), tidak kaku, tidak eksklusif, tidak elitis, tidak mengenal status quo, bisa berkembang, bisa mendongkrak kemapanan yang sudah tidak kondusif dan tentunya menerima dan mengenal adanya al-nadhhah (kebangkitan).

Jadi, Abl al-Sunnab Wa al-Jama'ah menurut Kiai Said Aqil Siroj adalah manhaj al-fikr (metode berpikir) dalam segala bidang kehidupan tidak terbatas akidah, syari'at dan tasawuf yang mengedepankan tawasut, tasamuh, tawazun dan i'tidal. Misalkan baik bidang sosial ekonomi politik budaya pendidikan maupun hubungannya dengan HAM. Sebagai contoh dalam ekonomi harus seimbang tidak kapitalis dan tidak terlalu sosialis mengakui barang pribadi dan mengakui barang milik umum.

\section{E. Penutup}

Pemikiran Kiai Said tentang teologi Abl al-Sunnah Wa al-Jama'ab dan HAM merupakan gagasan yang tidak hanya menggugah kaum muslim akan nilai-nilai universal kemanusiaan, tetapi juga membuka kesadaran yang dalam, argumentatif dan rasional bahwa doktrin Islam memang seharusnya demikian. Satu sisi dia berhasil menunjukkan buktibukti dalam teks suci dan menampilkan fakta-fakta sejarah universalitas dan komprehensivitas Islam. Di sisi yang lain dia sukses mengungkap kebutuhan-kebutuhan muslim di era globalisasi dan pluralisme.

Pendekatan filsafat sejarah yang ia gunakan, sebagai konsekuensi keilmuan yang dia tekuni,dalam menganalisis tema ini, benar-benar menunjukkan keluasannya dalam ilmu sejarah dan historiografi Islam.

${ }^{29}$ Ibid., 77. 
Setiap masalah ditelusuri dengan kenyataan-kenyataan historis yang tidak terbayangkan sebelumnya. Akar-akar historis peradaban Islam tentang pluralisme, kesetaraan (equality), kemerdekaan (freedom), keadilan (justice), demokrasi dan HAM itu sendiri. Selain itu Kiai Said juga menggunakan pendekatan linguistik dan semantik dalam memahami HAM. Sehingga dalam hal tersebut Abl al-Sunnab Wa al-Jama'ah tidak menjadi ajaran yang jumud, tidak kaku, tidak eksklusif, tidak elitis, tidak mengenal status quo, bisa berkembang, bahkan bisa mendongkrak kemapanan yang sudah tidak kondusif dan tentunya menerima dan mengenal adanya suatu kebangkitan. 


\section{Daftar Pustaka}

Aziz, Husein. Bahasa Al Qur'an Perspektif Filsafat Ilmu. Pasuruan: Sidogiri. 2002.

Harianto, Budi. "Tawaran Metodologi Fazlur Rahman dalam Teologi Islam”, Kontemplasi Jurnal Ilmu-Ilmu Ushuluddin, Vol. 04, No.02. Desember 2016.

Hasan, Hatta. Islam Kebangsaan Demokratik Kaum Santri. Jakarta: Fatma Press, 1999.

Hasan, Muhammad Tholhah. Ablssunnab wal Jama'ah dalam Persepsi dan Tradisi NU. Jakarta: Lantabora Press. 2005.

Iswahyudi. "Membongkar Hadis tentang Ahl Sunnah Wal Al-Jama'ah (Sebuah Pendekatan Critical Hermenutic: Jurgen Habermas", Hermenia Jurnal Kajian Islam Interdisipliner, vol.3, No.2, JuliDesember. 2004.

Lewis,Bernard, et al. Islam Liberalisme Demokrasi, Membangun Sinergi Warisan Sejarah, Doktrin dan Konteks Global, terj. Mun'im A Sirry. Jakarta: Paramadina, 2002.

Qomar, Mujamil. NU "Liberal" dari Tradisionalisme Ablssunnab ke Universalisme Islam. Bandung: Mizan. 2002.

Ramli, Muhammad Idrus. Madzhab Al-Asy'ari Benarkah Ablsunnah Wal Jama'ah? Jawaban terhadap Aliran Sesat. Surabaya: Khalista. 2009.

Sidney Hook (dkk). Hak Asasi Manusia dalam Islam .Jakarta: Pustaka Firdaus, 1995.

Siradj, Said Agiel. Ablssunnah Wal Jama'ah dalam Lintasan Sejarah. Yogyakarta: LKPSM. 1998.

Sururin (ed). Nilai-nilai Pluralisme dalam Islam .Bandung: Nuansa, 2005.

Spencer, Robert. Islam Ditelanjangi, terj. Mun'im A. Sirry .Jakarta: Paramadina,2004.

Syahban, Joko. Ensiklopedi NU. Pekalongan: Dwi Kaharjaning Gesang. 2010 .

Zuhri, Achmad Muhibbin. Pemikiran KH.M.Hasyim Asy'ari tentang Abl Al-Sunnah Wal Al-Jama'ah. Surabaya: Khalista. 2010. 